\title{
The Formation of Collagen Fibrils in the Dental Pulp
}

JAMES K. AVERY and SEONG S. HAN

School of Dentistry and School of Medicine, The University of Michigan, Ann Arbor, Michigan

In the last twenty years, because of the application of the electron microscope, there has been a considerable increase in knowledge concerning the origin and mechanism of formation of collagen. Since the work of Schmitt, Hall, and Jakus ${ }^{1}$ in 1942 illustrated that collagen was composed of a unit structure of fibrils, renewed interest has appeared in this area. Porter ${ }^{2}$ in 1952 and Wasserman ${ }^{3}$ in 1956 have reviewed the extensive work in this area and pointed out that the two controversial viewpoints of intracellular versus intercellular origin of collagen still persist. Fleming, ${ }^{4}$ Mall, ${ }^{5}$ Ferguson, ${ }^{6}$ and Lewis ${ }^{7}$ promoted the theory that collagen was formed within the cell. These beliefs were later supported by Jackson, ${ }^{8}$ Jackson and Smith, ${ }^{9}$ and Wasserman ${ }^{3},{ }^{10}$ by the observation of submicroscopic filaments or primary fibrils within the cytoplasm. On the other hand, Baitsell, ${ }^{11-13}$ Baitsell and Mason, ${ }^{14}$ Maximow, ${ }^{15}$ Nageotte and Guyon, ${ }^{16}$ Levi-Montalcini and Sacerdote, ${ }^{17}$ and more recently, Stearns ${ }^{18,}{ }^{19}$ and Kajikawa and Sumita ${ }^{20}$ point out that collagen is formed outside the cell in the ground substance. Studnicka, ${ }^{21}$ Porter, ${ }^{2}$ and Porter and Pappas ${ }^{22}$ have arrived at perhaps a third viewpoint in their belief that the collagen fibril components are developed extracellularly but at, or on the surface of, the fibroblast. Jackson ${ }^{23}$ and Jackson and Smith ${ }^{24}$ now support the theory that fibrogenesis is intimately associated with the surface of osteoblasts and chondroblasts, as does Wasserman, ${ }^{10}$ who observed bundles of primary fibrils at the surface of fibroblasts. Bradbury and $\mathrm{Meek}^{25}$ have recently illustrated collagen fibrils in the covering on the surface of fibroblasts in the leech. Weiss and Ferris $^{26}$ and $\mathrm{Kemp}^{27,28}$ came to a similar conclusion that procollagen units are derived from the fibroblasts. The majority of the recent evidence supports the premise that collagen is formed near, or in close conjunction with, the cell surface and that precursor substances are formed within the cell.

The tooth pulp has been described as being composed of a specialized connective tissue syncytium of stellate-appearing fibroblasts. 29,30 There have been few electronmicroscope studies of the pulp except those describing the fine structure of nerve fibers by Arwill, ${ }^{31}$ Matthews, Dorman, and Bishop, ${ }^{32}$ Uchizomo and Homma, ${ }^{33}$ and Engstrom and Ohman. ${ }^{34}$ To the authors' knowledge there have been no descriptions of where the collagen fibrils of the pulp arise. The present study was designed to obtain information about the morphologic characteristics of the pulp fibroblast and to gain some insight into the origin of the collagen fibrils of the pulp.

This study was supported by the Research and Development Division, Office of the Surgeon General, Department of the Army under contract No. DA-49-007-MD909 and The University of Michigan Graduate Research Fund, Project No. 1038.

Received for publication February 22, 1961. 


\section{MATERIALS AND METHODS}

Eighty young molar tooth buds were removed from newborn hamsters and fixed for $1 \frac{1}{2}$ hours in either 2 per cent osmium tetroxide buffered at pH 7.2 with veronal acetate or in 2.4 per cent potassium permanganate ${ }^{35}$ with $0.14 \mathrm{M}$ veronal acetate buffer and calcium chloride added to make a 0.1 per cent solution. The molar tooth buds, measuring less than 1-2 mm. in diameter, were fixed without trimming and then dehydrated in $30,50,70,80$, and 95 per cent absolute ethyl alcohol for a total time of 1 hour and 30 minutes. The tissues were infiltrated in equal parts of absolute alcohol and butyl methacrylate for 30 minutes and then in 100 per cent butyl methacrylate for 30 minutes. The tissues were then placed in an 80 per cent butyl methacrylate and 20 per cent methyl methacrylate mixture for 30 minutes, after which time the catalyst* was added, and the tissues were allowed to stand 30 minutes. Then they were transferred to gelatin capsules containing catalyzed 80:20 butyl:methyl methacrylate mixture and placed for 30 minutes in a vacuum chamber at 15 inches $\mathrm{Hg}$. The capsules were then placed in a $50^{\circ} \mathrm{C}$. oven for curing. After 24 hours the plastic-imbedded tissues were sectioned on a microtome $\dagger$ at approximately 25-90 millimicrons.

\section{RESULTS}

The potassium permanganate appeared to provide better fixation of cell membranes, certain intracellular structure, and ground substance of young pulp than did the osmium tetroxide in the manner used. Apparently, the gelatinous young pulp, surrounded by dentin and enamel matrix, was penetrated less effectively by the $\mathrm{OsO}_{4}$ than by the $\mathrm{KMnO}_{4}$. The observations of the present study therefore will be confined to the permanganate-fixed material.

Fibroblasts.- In young pulp tissue the cells found in greatest numbers were the fibroblasts or fibrocytes. These cells appeared to vary in shape, most of them having a stellate appearance with from one to several cell processes seen in any plane (Figs. 14 ). The width of the cell body ranged from 9 to $15 \mu$. The cell processes were found to reach $22 \mu$ in length or even longer. The fibroblasts did not form a true syncytium with adjacent cells. The cell membranes were observed to inclose the cytoplasm completely, and desmosome-like structures were noted between cell processes and probably functioned in attachment between cells (Figs. 3 and 13). Most cells had round or ovalshaped nuclei with two or three small, indistinct nucleoli (Figs. 3 and 4). The nucleoplasm and the nucleoli appeared less electron-dense with $\mathrm{KMnO}_{4}$ than with $\mathrm{OsO}_{4}$. The nuclear membrane was found to be double (Figs. 4 and 10), exhibiting the characteristic pores (Fig. 4). The cytoplasm of the cells appeared densely populated with oval mitochondria and, to a lesser extent, with endoplasmic reticulum (Figs. 3-5). A few mitochondria varied considerably from the oval shape, ranging in length from 0.5 to $6 \mu$ (Fig. 7), but the average size was found to be $0.75 \mu$ in length. The mitochondria did not appear to have regularly spaced cristae mitochondriales extending across the structure. The double external membranes of the mitochondria and the cristae mitochondriales were clear, the membranes being thinner than the cristae (Figs. 7 and 12). The endoplasmic reticulum was not highly organized and was scattered in tubular

\footnotetext{
* Luperco CDB, Wallace and Tiernan, Inc., 1740 Military Road, Buffalo, N.Y.
}

$\uparrow$ Porter-Blum. 


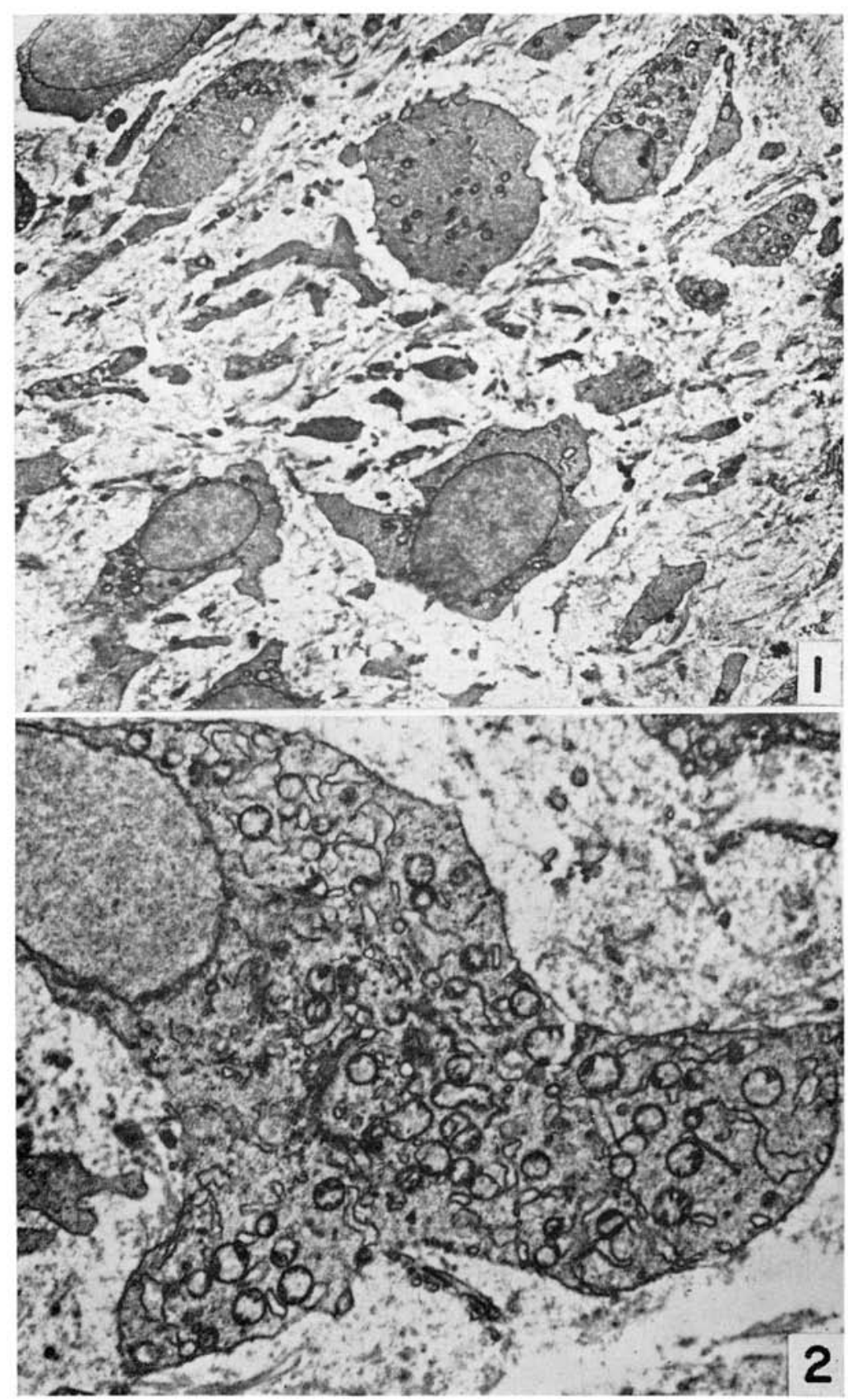

FIG. 1.-The central zone of young pulp, illustrating numerous fibroblasts and collagen fibrils scattered throughout the area. (Total mag. $\times 2,000$.)

Fig. 2.-A typical fibroblast illustrating the oval, lightly stained nucleus. Numerous mitochondria are seen scattered throughout the cytoplasm. The Golgi apparatus is located near the nucleus. Numerous collagen fibrils are visible near the cell processes. (Total mag. $\times 4,693$.) 

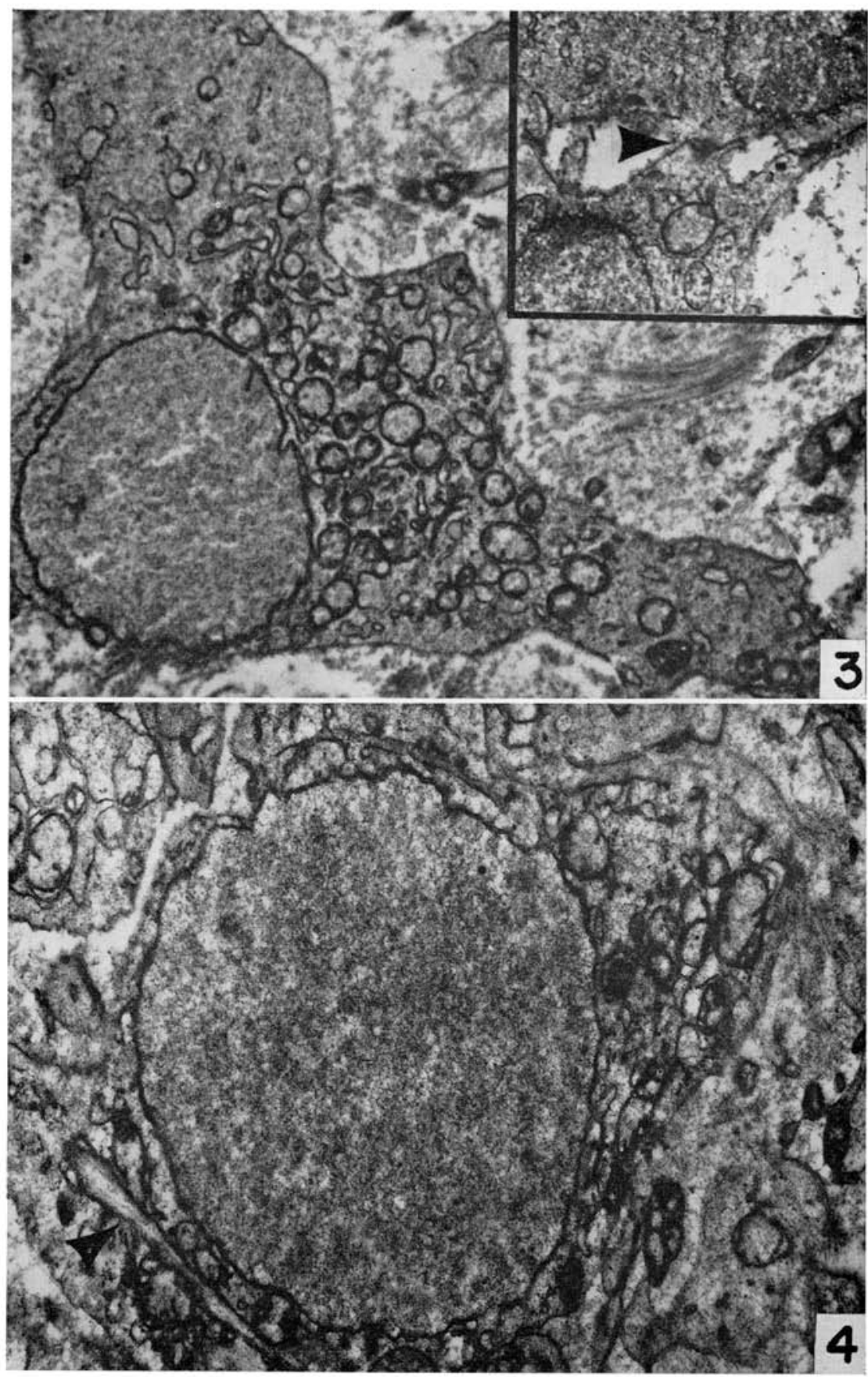

Fig. 3.-A fibroblast of the young pulp with cell processes extending above and to the right. A small nucleolus is seen in the left part of the nucleus. Absence of, or decrease in number of, cristae mitochondriales in many of the mitochondria may indicate that they are immature. (Orig. mag. $\times 5,280$.) The insert in the upper right corner illustrates an intercellular attachment between two fibroblasts. The nuclei of the two cells are seen in the upper right and lower left. (Total mag. $\times 5,675$.)

Fic. 4.-A higher magnification of a fibroblast with an oval nucleus. An island of collagen fibrils surrounded by a membrane appears near the point of the arrow (lower left). This inclusion is probably due to an infolding of the outer cell membrane along with the adjacent fibrils. (Total mag. $\times 7,548$.) 


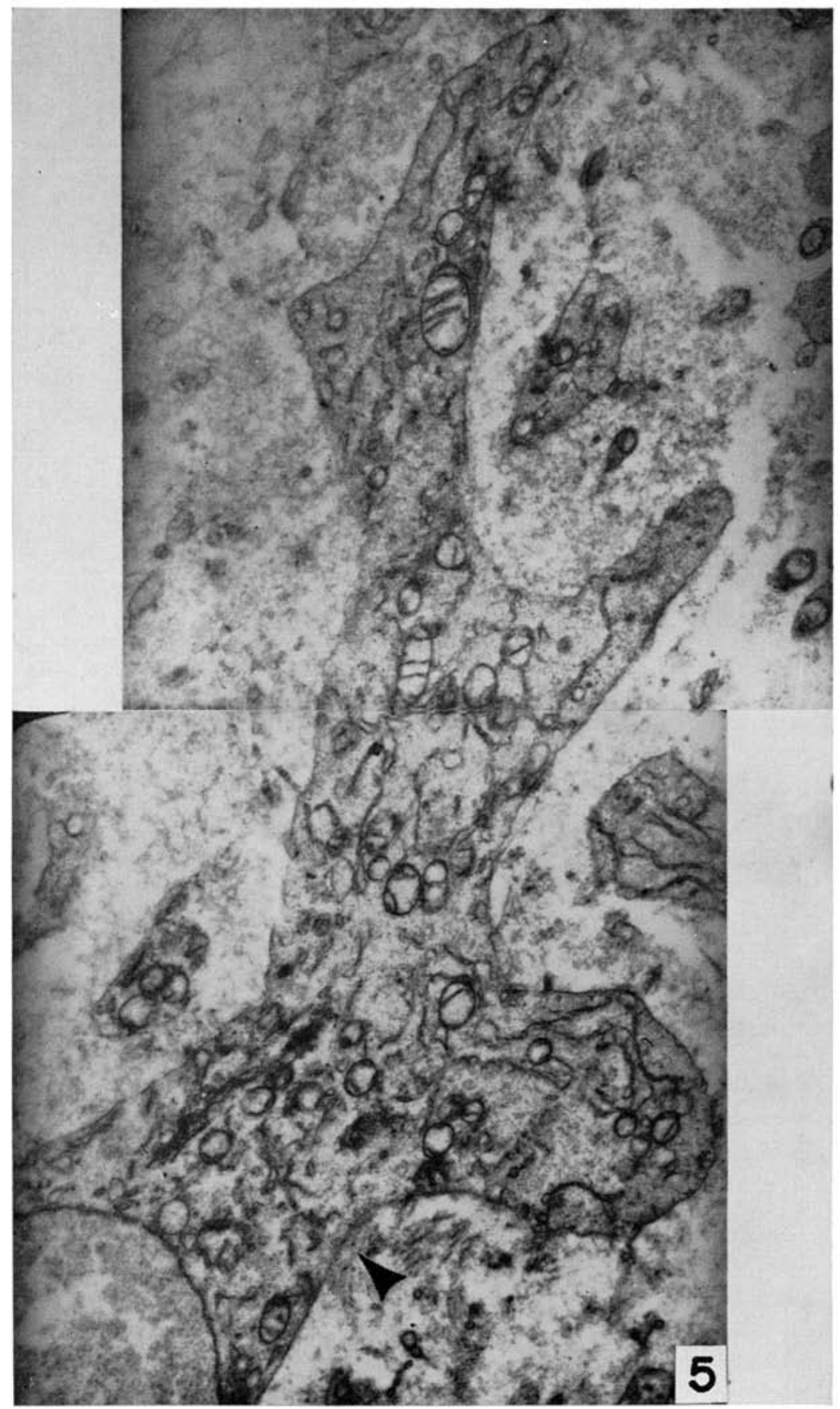

FIG. 5.-A composite electronmicrograph of a pulpal fibroblast and three of its processes. Part of the nucleus is shown (lower left). The Golgi apparatus is visible near the nucleus. Endoplasmic reticulum and numerous mitochondria are scattered throughout the cytoplasm. The arrow points to collagen fibrils located near the surface of the cell. (Total mag. $\times 6,875$.) 


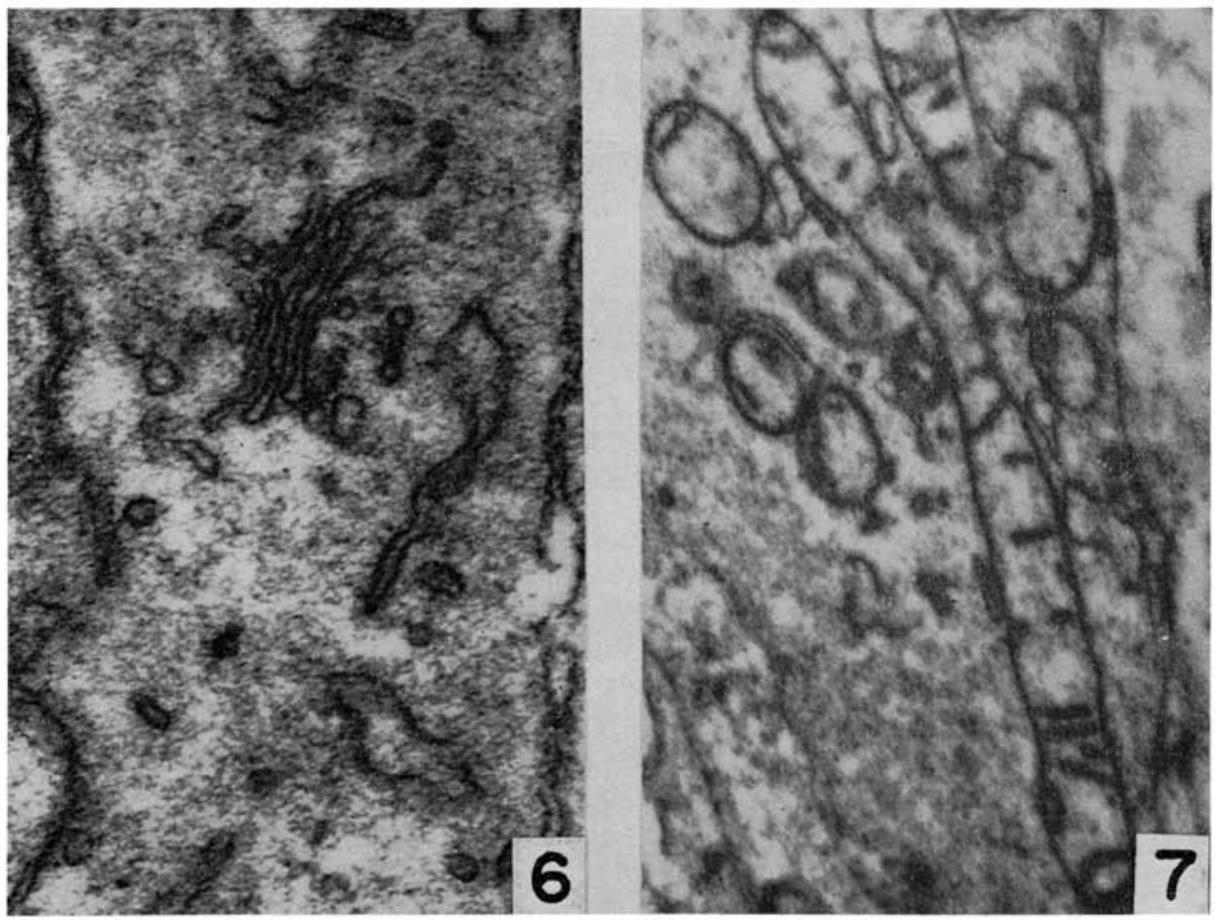

FIG. 6.-A high-magnification electronmicrograph of a typical Golgi apparatus in a pulp fibroblast. It appears as a group of bilaminar structures with closed ends and several vesicles. (Total mag. $\times 43,200$.)

FIG. 7.-A high-magnification electronmicrograph of typical mitochondria of pulp fibroblasts illustrating the great variations in length of these structures. The mitochondrion on the right measures $6.7 \mu$. The cristae mitochondriales are few in number and randomly spaced. (Total mag. $\times 14,900$.)

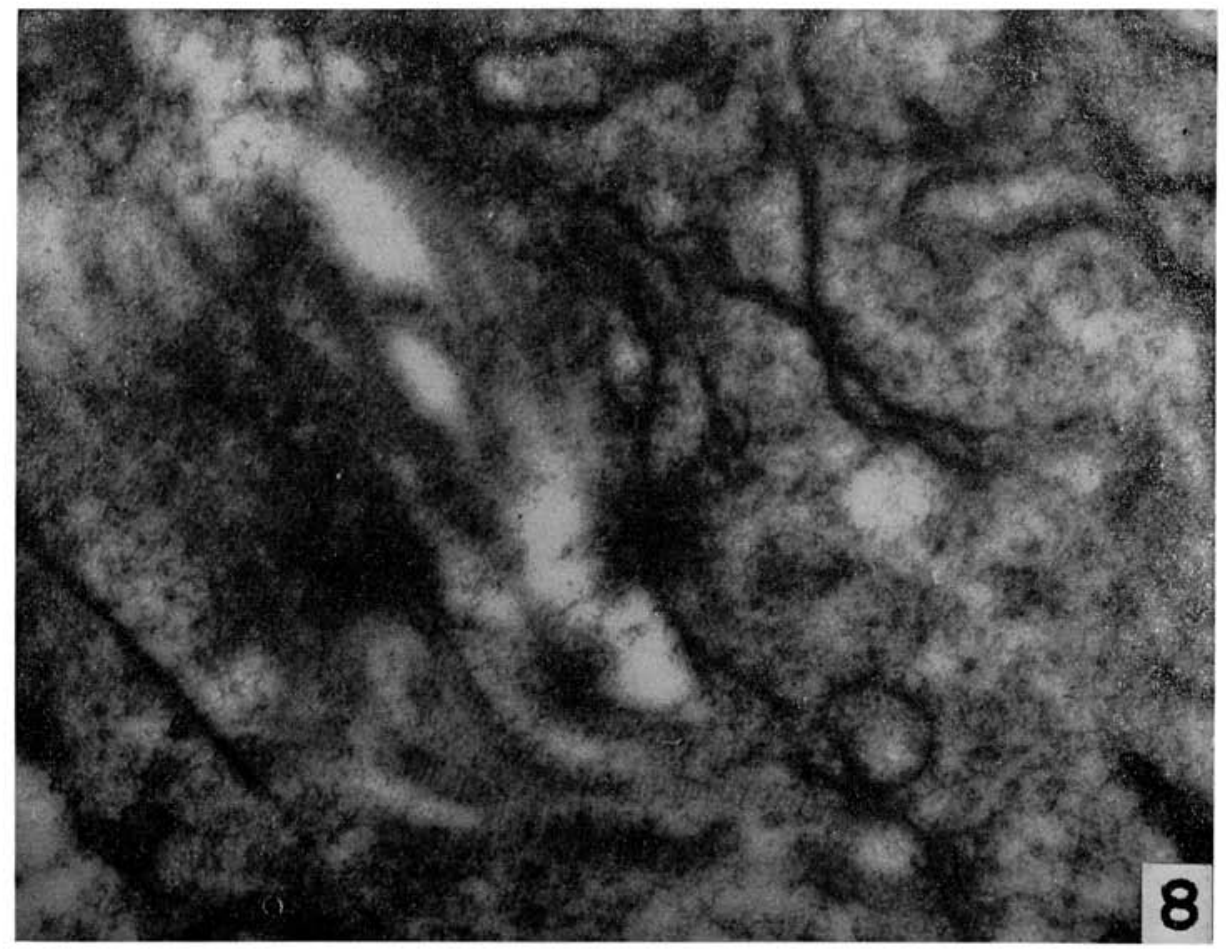

FIG. 8.-A high-magnification electronmicrograph of collagen fibrils near the outer cell membrane of the fibroblast. The collagen periodicity is noticeable. (Total mag. $\times 46,080$.) 

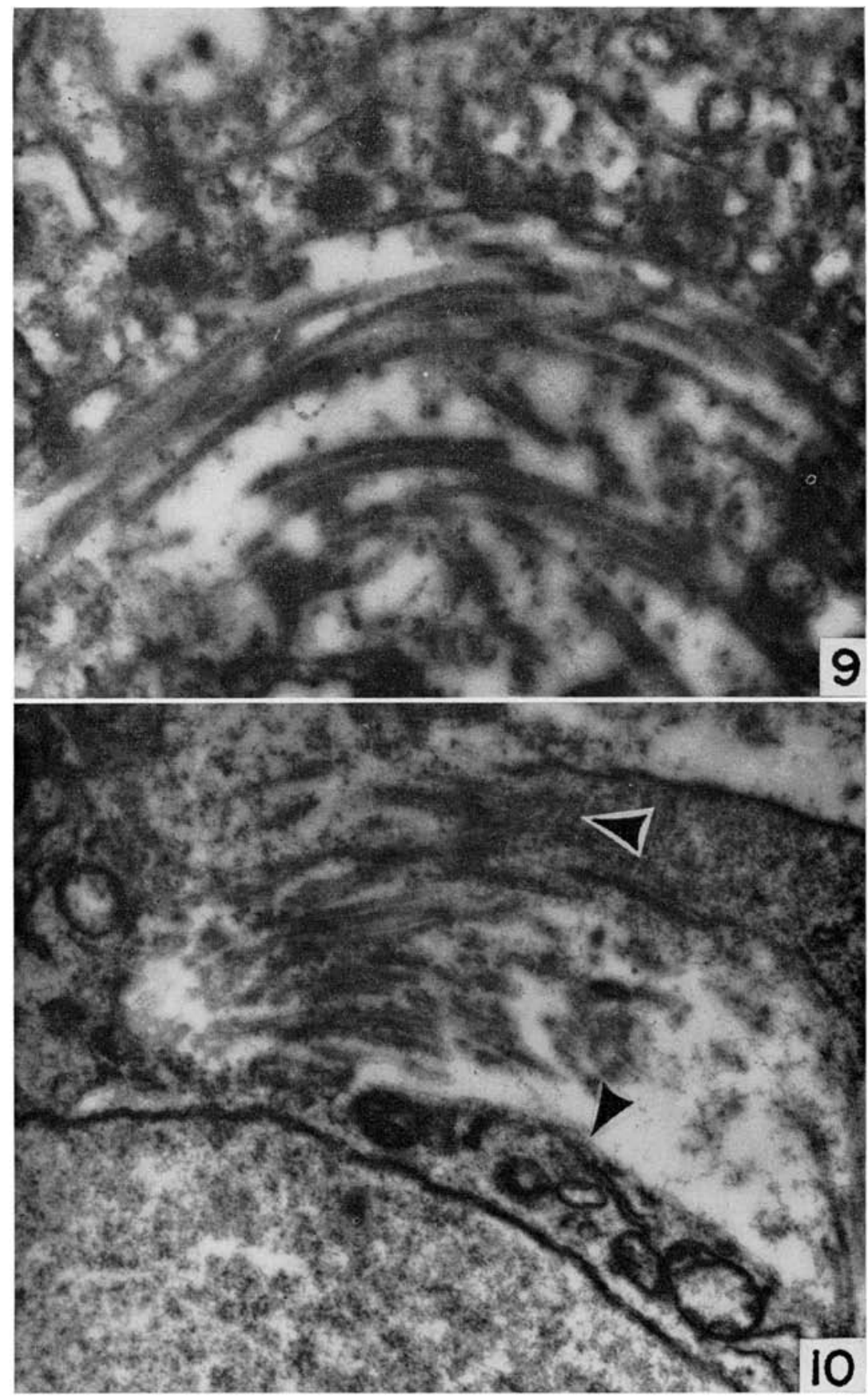

FIG. 9.-Numerous collagen fibrils lying near the outer cell membrane of a fibroblast process in the pulp. The single layer of the outer cell membrane is visible. (Total mag. $\times 23,936$.)

Fig. 10.-Young collagen fibrils lying near the surface of a pulp fibroblast. Near the point of the upper arrow some fibrils appear to be located within the cytoplasm of the cell. This appearance is believed due to the presence of the fibrils lying adjacent to the outer cell membrane, which lies either immediately above or below this section. In the lower part of the picture is seen the double membrane of the nucleus with a narrow zone of cytoplasm just above it. The outer cell membrane is indistinct, and a collagen fibril (lower arrow) lies in close approximation with the cell surface. (Total mag. $\times 17,770$. 

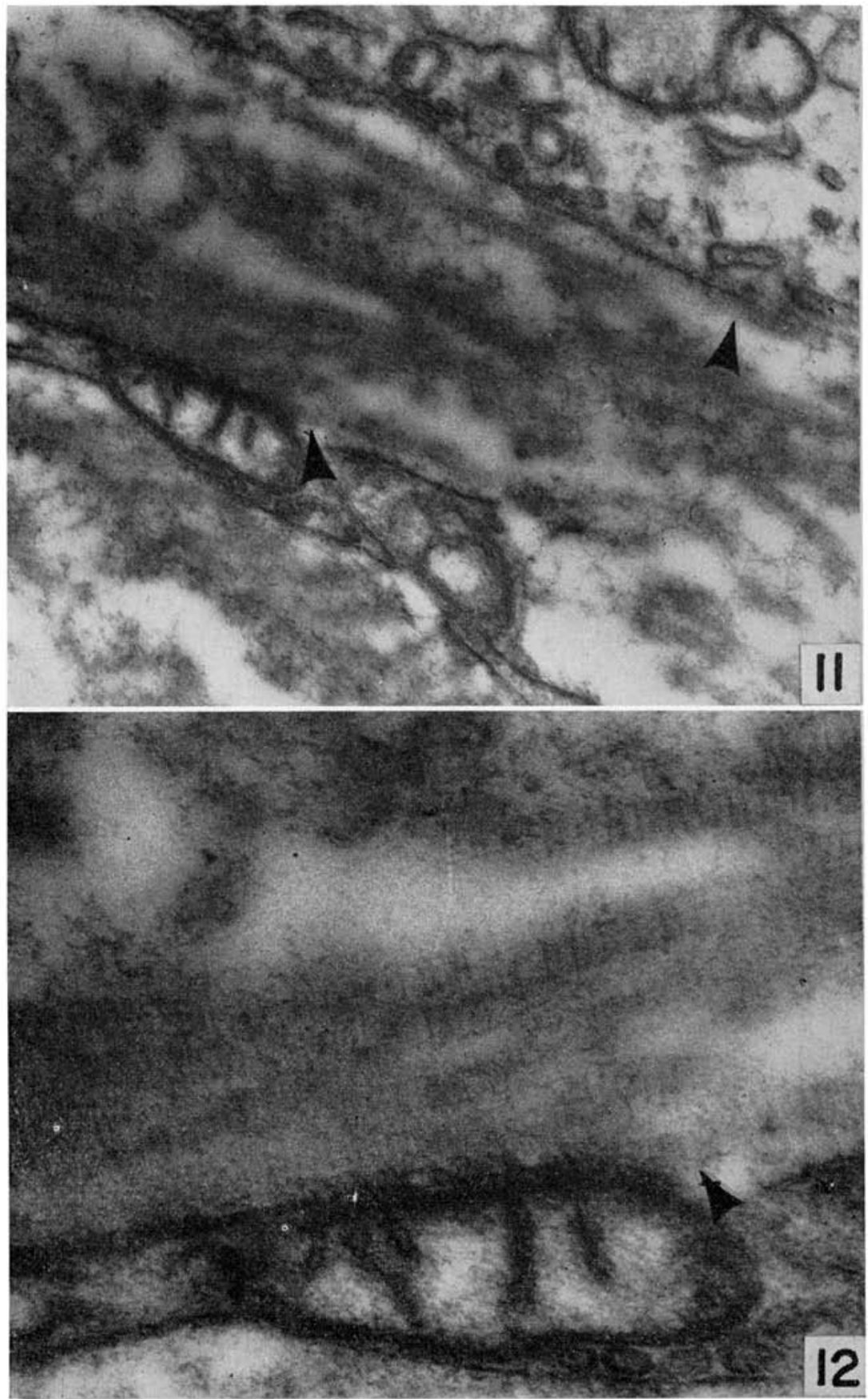

Fig. 11.-Young collagen fibrils lying in contact with the outer cell membranes of pulp fibroblasts. Near the points of the arrows the collagen fibrils appear to be in contact with, or imbedded in, the cell surface. (Total mag. $\times 26,293$.)

Fig. 12.-A higher magnification of the lower half of Fig. 11. The double wall of the mitochondrion is seen in near contact with the single-layer cell membrane. The outer part of the cell wall appears "ruffled" or altered, and at the point of the arrow is seen one end of a collagen fibril, which appears to be imbedded in, or lying in contact with, the cell wall to the left. (Total mag. $\times 68,000$.) 
form throughout the cell (Fig. 5). With $\mathrm{KMnO}_{4}$ fixation the ribosome granules were not preserved and thus not apparent on these structures (Fig. 8). The Golgi apparatus was located near the nuclei of these cells and appeared as clusters of short, bilaminar membranes with several associated vesicles (Figs. 2, 5, and 6). In some instances the bilaminar components appeared straight, while in other cells they formed semilunarshaped structures. The cytoplasm appeared granular, with no increase in density seen in any particular area of the cell or its processes. A number of small rodlets, particulate matter, and other electron-dense structures appeared scattered throughout the cytoplasm of the cell.

The fibrils of the intercellular substance.-In the area immediately surrounding the cell, numerous bundles of fibrils were scattered in the ground substance (Figs. 1-3 and 5). Examination at higher magnifications revealed that these fibrils had the banding characteristic of collagen. It was observed that many of these fibrils lay in close association with the cell and, in some instances, in contact with the outer cell membrane (Figs. 8-12). At times the fibrils were lying at right angles to the cell surface but usually were found in a plane similar to that of the outer surface of the cell.

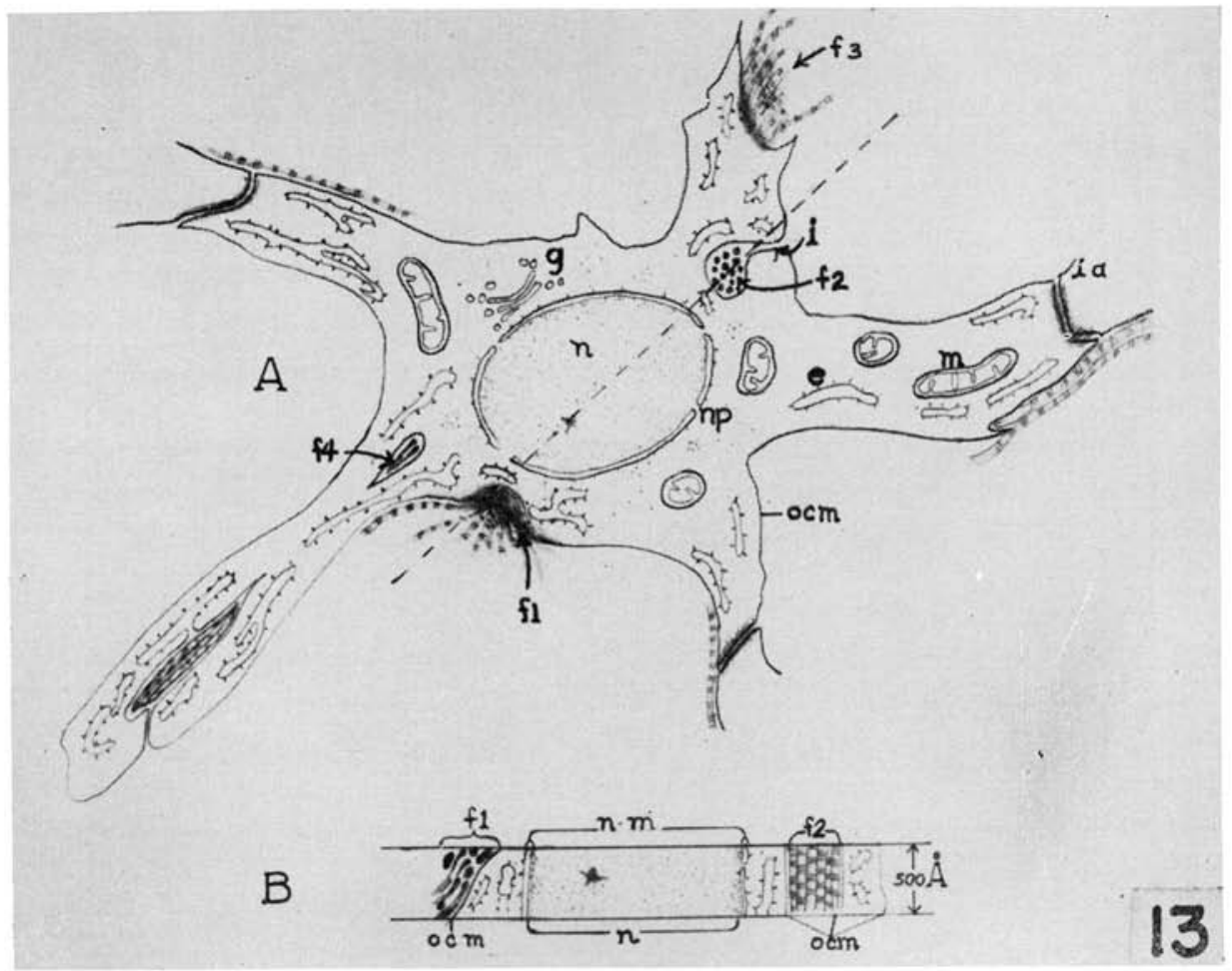

FIg. 13.-A diagrammatic representation of the electron-microscopic appearance of a young pulpal fibroblast as visualized in the present study. $A$ : Top view of a sectioned fibroblast. $B$ : A cross-section view of the $500 \mathrm{~A}$-thick section $A$ along dotted line. $n$, nucleus; $n m$, nuclear membrane; $n p$, nuclear pore; ocm, outer cell membrane; $g$, Golgi apparatus; $m$, mitochondria ; $e$, endoplasmic reticulum; $i$, infolding membrane; $i a$, intercellular attachment. Fibrils ( $f 1$ and $f 3$ ) superimposed on the sloped portions of the outer cell membrane will cause the cell membrane to be completly obscured, producing the appearance of cytoplasmic continuity with the fibrils. At area $f 2$ the fibrils appear to be completely surrounded by cytoplasm, as in $f 4$. 
Although the majority of the fibrils were closely associated with the cell processes, some were found adjacent to the cell body as well. In some electronmicrographs the fibrils appeared to have an intracellular location. The observation was believed to be an artifact because of the following reasons. In some cases the intracellular fibrils appear located in a space which is completely surrounded by a membrane which appears structurally very much like the outer cell membrane (Fig. 4). Since the outer cell membrane follows a tortuous course, it is believed possible that an infolding of the cell surface and adjacent fibrils could be included in any section through the cell. Other groups of fibrils appeared to be located within the cytoplasm near the cell surface. In these cases no outer membrane confining the fibrils was observed within the cell (Fig. 10). In such instances it was believed that the section was made almost parallel to the surface of a fibril-covered outer membrane, which then slanted upward out of the plane of section. However, the membrane is so thin and in such close contact with the fibrils that it cannot be distinguished from the cut ends of the fibrils, causing them to appear to be in contact with the cytoplasm. A diagrammatic explanation of the authors' interpretation of the finding of apparently intracellular collagen fibrils is shown in Figure 13. In a few cases collagen fibrils with a diameter of 100 $300 \mathrm{~A}$ were observed imbedded in, or in close association with, the outer membrane of the cell (Figs. 10-12). In Figures 11 and 12 it can be seen that some alteration has possibly occurred in the cell membrane in the area where a fibril is located. Although the cell membrane is intact in these areas, the outer portion of it appears altered in respect to the adjacent fibril. Measurements were made of the diameter and periodicity of the numerous collagen fibrils throughout the pulp. At a distance from the cell surface the fibrils were found to measure approximately 200-400 A in diameter and to exhibit $458 \mathrm{~A}$ periodicity. It was not possible to obtain accurate measurements of the length of the fibrils because an entire fibril was probably not included in the plane of a single thin section.

\section{DISCUSSION}

The young fibroblasts found in the hamster dental pulp appear somewhat less differentiated than fibroblasts found in the adult rat. ${ }^{36,} 37$ The nucleoli of the young pulp fibroblasts are smaller, the mitochondria are less differentiated, and the endoplasmic reticulum is more sparse or less highly developed. In the adult fibroblasts the perinuclear cytoplasm is more dense than that found in their processes, whereas the density of the cytoplasm in the young pulpal fibroblasts does not vary throughout the cell and its processes. These variations in characteristics may indicate that the cells found in the young pulp are not fully differentiated. On the other hand, these cells appear differentiated sufficiently to function in fibril production. Perhaps they will develop into more mature cellular elements of the pulp which function in the formation of collagen fibrils important to dentinogenesis. Further studies on these cells is necessary before such conclusions can be made, however.

The present study indicated that collagen fibrils of the dental pulp were formed at the surface of the pulp fibroblast. These young fibrils measured only $250 \mathrm{~A}$ in diameter, as compared to those measuring $600 \mathrm{~A}$ found in hamster dentin by Watson and Avery. ${ }^{38}$ On the other hand, those authors found collagen fibrils measuring 100 $300 \mathrm{~A}$ in diameter along the dentinal tubule in predentin, which indicated that some 
fibrils were first deposited in the peritubular region and continued with age to increase in diameter. Porter and Pappas ${ }^{22}$ noted fibrils in the region of the cell surface of chick fibroblasts to be 200-300 A in diameter. It is their belief that fibrils smaller than $600 \mathrm{~A}$ grow by addition to their surface of monomeric collagen and not by association with groups of fibrils. It is not understood why the short periodic lengths of $458 \mathrm{~A}$ were found in the present study. It is possible that the $640 \mathrm{~A}$ period characteristic of collagen was not fully established in these fibrils and that further organization of these fibrils occurred until the 640 A banding was attained.

Little is known concerning the mechanism of formation of collagen precursors by the fibroblasts. Jackson ${ }^{8}$ and Jackson and Smith $^{9}$ showed intracytoplasmic rodlets which they believed to be precursors of collagen. Perhaps if Palade's $s^{39,40}$ theory of continuity of the endoplasmic reticulum with the cell membrane is correct, the possibility of intracisternal proteinic materials directly secreted into the intercellular spaces can be readily explained. However, there are claims by Karrer ${ }^{41}$ that the unit structure of the cell membrane is different from that of the endoplasmic reticulum. Gross, Highberger, and Schmitt ${ }^{42}$ suggest that collagen in a monomeric form is developed within the cell and is transformed into fibrils extracellularly. Porter ${ }^{2}$ and Porter and Pappas ${ }^{22}$ believe that the cell surface functions in some way that aids in the formation of the collagen template. Possibly at this site, polymerization of the forming substances may occur.

The findings in the present study can be interpreted in several ways in respect to fibrogenesis. Intracytoplasmic fibrils were noted, which could indicate intracellular formation, but these were believed to be present as a result of infolding of the outer cell membrane, since cell membranes were clearly visible surrounding groups of these fibrils. Other fibrils within the cytoplasm did not appear to be surrounded by membranes. In a $500 \mathrm{~A}$-thick section, such as the ones in this study, it was believed possible for the outer membrane to be obscured by the cut ends of the fibrils as both slanted upward out of the plane of section.

It is apparent that the authors are avoiding the conclusion that unit fibrils are formed intracellularly. This is due partially to the fact that the apparently intracellular fibrils noted in the present investigation can be explained as being intercellular and also because the majority of findings by other investigators indicate that, although the procollagen molecules may be formed within the fibroblast, the unit fibril becomes recognizable extracellularly. In the case of the fibroblasts of the young pulp, the fibrils appear near or along or partly within the outer cell membranes. It is, therefore, possible that the outer membrane of the cell does play some part in the formation of these fibrils, as was believed by Porter and Pappas. ${ }^{22}$

It is indicated that further studies of the internal structure of fibroblasts and their membranes must be made before conclusions concerning the precise role of cytoplasm in collagen formation can be drawn. It is obvious from the present investigation that the dental pulp offers an excellent site for such studies. Although the young pulp fibroblasts studied appeared to be less differentiated than fibroblasts found in other areas of the adult animal body, ${ }^{36}$ this was probably due to the embryonic nature of the young pulp. It will be necessary to study the fibroblasts at various ages of the pulp before their characteristics can be described fully. 


\section{SUMMARY AND CONCLUSIONS}

Eighty molar buds from newborn hamsters were fixed in either $\mathrm{KMnO}_{4}$ or $\mathrm{OsO}_{4}$, imbedded in methacrylate, sectioned on a Porter-Blum microtome, and studied under the electron microscope. The $\mathrm{KMnO}_{4}$ fixation was found to be far superior to $\mathrm{OsO}_{4}$ for the study of the membranes of fibroblasts and fibril formation in young pulp.

The fibroblasts in young pulp were found to have an outer cell membrane completely inclosing the cytoplasm. Therefore, they do not form a true syncytium but establish contact with each other by means of intercellular attachments.

The cytoplasmic characteristics of fibroblasts in young pulp appeared somewhat different from those of fibroblasts found in connective tissue in adult animals. A lesser amount of endoplasmic reticulum was found, and the mitochondria in the young cells had fewer cristae mitochondriales. The electron density of the cytoplasm of the cell body was observed to be similar to that of its processes.

Intracellular location of collagen fibrils was observed but was believed to be artifactual and caused by sectioning through infolding membrane or oblique sectioning of the outer cell membrane. Many collagen fibrils measuring 100-300 A in diameter and having a periodicity of $458 \mathrm{~A}$ were observed near, or in contact with, the outer cell membrane of the fibroblast. Other collagen fibrils measuring 200-400 A in diameter were noted farther from the cell surface.

It is believed that the fibroblasts of the dental pulp function in the production of collagen fibrils on or within the outer membrane of the cell.

The authors wish to express their sincere appreciation to Miss Elizabeth Haley and Mr. Jamal Asgarzadeh for technical assistance in preparation of the thin sections and to Mr. Herbert Andre for preparation of the photographs.

\section{REFERENCES}

1. SchMitT, F. O., HaLl, C. E., and JAKUS, M. A. Electromicroscopic Investigations of the Structure of Collagen, J. Cellular Comp. Physiol., 30:11, 1942.

2. Porter, K. R. Repair Processes in Connective Tissues, in Connective Tissues: Transactions of the Second Conference, pp. 126-58. New York: Josiah Macy, Jr., Foundation, 1952.

3. WAsserman, F. The Intercellular Components of Connective Tissue: Origin, Structure and Interrelationship of Fibers and Ground Substance, Ergeb. Anat. u. Entwicklungsgeschichte, 35:241, 1956.

4. FLEMING, W. Über die Entwicklung der collagenen Bindegewebsfibrillen bei Amphibien und Säugethieren, Arch. J. Anat. u. Entreicklungsgeschichte, p. 171. Leipzig, 1897.

5. MaLi, F. P. On the Development of the Connective Tissues from the Connective-Tissue Syncytium, Am.J. Anat., $1: 329,1902$.

6. Frrguson, J. S. The Behavior and Relations of Living Connective-Tissue Cells in the Fins of Fish Embryos with Special Reference to the Histogenesis of the Collagenous or White Fibers, Am. J. Anat., 13:129, 1912.

7. Lewrs, M. R. Development of Connective-Tissue Fibers in Tissue Cultures of Chick Embryos, Contribs. Embryol., 6:47, 1917.

8. JACkson, S. F. The Formation of Connective and Skeletal Tissues, Proc. Roy. Soc. London, B, 142: $536,1954$.

9. JACrson, S. F., and Smith, R. H. Fibrogenesis of Connective and Skeletal Tissues in the Embryonic Fowl, in Fibrous Proteins and Their Biological Significance, pp. 89-96. New York: Academic Press, Inc., 1955.

10. WASSERMAN, F. Fibrillogenesis in the Regenerating Rat Tendon with Special Reference to Growth and Composition of the Collagenous Fibril, Am. J. Anat., 94:399, 1954. 
11. Bartsell, G. A. The Origin and Structure of a Fibrous Tissue Which Appears in Living Cultures of Adult Frog Tissues, J. Exptl. Med., $21: 455,1915$.

12. - . A Study of the Development of Connective Tissue in the Amphibia, Am. J. Anat., 28:447, 1921.

13. - On the Origin of the Connective-Tissue Ground-Substance in the Chick Embryo, Quart. J. Microscop. Sci., 69:571, 1925.

14. Baitsell, G. A., and Mason, K. E. The Transformation of Adipose Tissue Following Experimental Tuberculosis, Am. Rev. Tuberc., 29:587, 1934.

15. Maximow, A. Development of Argyrophile and Collagenous Fibers in Tissue Culture, Proc. Soc. Exptl. Biol. Med., $25: 439,1925$.

16. Nageotre, J., and Guyon, L. Considérations générales sur la trame conjonctive, Arch. biol., $41: 1$, 1931.

17. Levi-Montarcini, R., and Sacerdote, E. I Caratteri e le modalità di sviluppo delle fibre collagene e reticolari nelle colture in vitro, Arch. ital. anat. e embriol., 40:37, 1938.

18. Stearns, M. L. Studies on the Development of Connective Tissue in Transparent Chambers in the Rabbit's Ear. I, Am.J. Anat., 66:133, 1940.

19. - Studies on the Development of Connective Tissue in Transparent Chambers in the Rabbit's Ear, II, ibid., 67:55, 1940.

20. Kajikawa, K., and Sumita, Y. Electron Microscopic Studies on the Connective Tissue. I. The Structure of the Normal Loose Connective Tissue Fiber and Its Formation, Acta path. Japon., 3:66, 1953 .

21. Studnicka, F. K. Die Entwicklung der Bindegewebsfibrillen (Desmofibrillen): Zugleich ein Kapitel aus der Geschichte der Histologie, Ergeb. Anat., 34:369, 1944.

22. Porter, K. R., and Pappas, G. D. Collagen Formation by Fibroblasts of the Chick Embryo Dermis, J. Biophys. Biochem. Cytol., 5:153, 1959.

23. Jackson, S. F. The Fine Structure of Developing Bone in the Embryonic Fowl, Proc. Roy. Soc. London, B, 146:270, 1957.

24. Jackson, S. F., and Smitr, R. H. Studies on the Biosynthesis of Collagen. I. The Growth of Fowl Osteoblasts and the Formation of Collagen in Tissue Culture, J. Biophys. Biochem. Cytol., 3:897, 1957 .

25. Bradbury, S., and Meek, G. A. A Study of Fibrogenesis in the Leech, Hirudo medicinalis, Quart.J. Microscop. Sci., 99:143, 1958.

26. Werss, P., and Ferris, W. The Basement Lamella of Amphibian Skin. Its Reconstruction after Wounding, J. Biophys. Biochem. Cytol., 2:275, 1956.

27. Kemp, N. E. Development of the Basement Lamella of Larval Anuran Skin, Develop. Biol. I : 459, 1959.

28. - Replacement of the Larval Basement Lamella by Adult-Type Basement Membrane in Anuran Skin during Metamorphosis, ibid., 3:391,1961.

29. ORBAN, B. J. Oral Histology and Embryology, p. 143. St. Louis: C. V. Mosby Co., 1957.

30. Schour, I. Noyes' Oral Histology and Embryology, p. 145. 8th ed. Philadelphia: Lea \& Febiger, 1960.

31. ArwiLl, T. Innervation of the Teeth-a Study by Light and Electron Microscopy, Trans. Roy. D. School Stockholm and Umea, No. 3, pp. 7-88, 1958.

32. Matthews, J. L., Dorman, H. L., and Bishop, J. G. Fine Structure of the Dental Pulp, J. D. Res., 38:940, 1959.

33. Uснтzомо, K., and Hоммa, K. Electron Microscope Studies on Nerves of Human Tooth Pulp, J. D. Res., 28:1133, 1959.

34. Engstrom, H., and Ohman, A. Studies on the Innervation of Human Teeth, J. D. Res., 39:799, 1960.

35. Luft, J. H. Permanganate-a New Fixative for Electron Microscopy, J. Biophys. Biochem. Cytol., $2: 799,1956$.

36. HaN, S. The Ultrastructure of the Lymph Nodes of the Rat. Thesis, University of Michigan School of Medicine, 1961. Am.J. Anat. (In press.)

37. BaKer, B., and HAN, S. Connective Tissue. I. Its Study by Histochemistry with Emphasis on Oxidative Enzymes. II. Electron Microscopy of Reticular Cells in the Lymph Node, Conference on the Biology of Connective Tissue Cells. (In press.)

38. WATSON, M. L., and AvERY, J. K. The Development of the Hamster Lower Incisor as Observed by Electron Microscopy, Am.J. Anat., $95: 109,1954$. 
39. Palade, G. E. Relations between the Endoplasmic Reticulum and the Plasma Membrane in Macrophage, Anat. Rec., $121: 445,1955$ (Abstr.).

40. - - The Endoplasmic Reticulum, J. Biophys. Biochem. Cytol., 2:85, 1956 (Suppl.).

41. Karrer, H. E. Electron Microscopic Study of the Phagocytosis Process in the Lung, J. Biophys. Biochem. Cytol., 7:357, 1960.

42. Gross, J., Highrerger, J. H., and Schmitr, F. O. Extraction of Collagen from Connective Tissue by Neutral Salt Solutions, Proc. Natl. Acad. Sci., 41:1, 1955. 